\title{
PERSONAL NAMES AND DENOMINATION OF LIVONIANS IN EARLY WRITTEN SOURCES
}

\author{
Enn Ernits \\ Estonian University of Life Sciences
}

\begin{abstract}
This paper presents the timeline of ethnonyms denoting Livonians; specifies their chronology; and analyses the names used for this ethnos and possible personal names. If we consider the dating of the event, the earliest sources mentioning Livonians are Gesta Danorum and the Tale of Bygone Years (both 10th century), but both sources present rather dubious information: in the first the battle of Bråvalla itself or the date are dubious (6th, 8th or 10th century); in the latter we cannot be sure that the member of the Rus delegation was really a Livonian. If we consider the time of recording, the earliest sources are two rune inscriptions from Sweden (11th century), and the next is the list of neighbouring peoples of the Russians from the Tale of Bygone Years (12th century). The personal names Bicco and Ger referred in Gesta Danorum, and Либи Аръфастовъ in Tale of Bygone Years are very problematic. The first certain personal name of a Livonian is *Mustakka, *Mustukka or *Mustoikka (from Finnic *musta 'black') written in 1040-1050s on a strip of birch bark in Novgorod.
\end{abstract}

Keywords: Livs, Finnic peoples, ethnonyms, anthroponyms, onomastics

DOI: http://dx.doi.org/10.12697/jeful.2014.5.1.01

\section{Introduction}

This paper (1) seeks to present the timeline of ethnonyms denoting Livonians; (2) to specify their chronology; (3) and to analyse the names used for this ethnos and possible personal names. It is supplemental to the paper by Mauno Koski on words denoting Livonians (Koski 2011).

When we start arranging written sources chronologically, two aspects must be made clear: on the one hand we have the time of the event recorded retrospectively; on the other we have the time of the event of recording it. Also, a third aspect must be taken into consideration - namely the time of creating the preserved copy of a chronicle, normally rewritten with amendments numerous times. Unfortunately some of the data is uncertain: sometimes it is unclear whether the event took place at all, and sometimes the date of the event is unclear. 


\section{Uncertain information}

Ethnonyms with stems of interest to this research are mentioned as far back as by Roman authors of the 1 st and 2 nd centuries. Pliny the Elder (23-79) mentions the people living in the 500 (!) districts of Skatinavia island in his Naturalis Historia and calls them Hilleviones. Publius Cornelius Tacitus (55-120) speaks in his Germania about a people called the lemovii or levonii. Claudius Ptolemy (90-160) writes about an island called Skandia, where in the northern part live Phinnoi, in the southern part Goutai and Daukiones, while the central part of this island is inhabited by Leuonoi. All of these ethnonyms with the lev-stem were linked to the name Livonians as early as the 18th century (Koski 2011: 57). The stem levio- levo- $\sim$ leuo- does appear to be like the name Livonians, but in other places the name Leuonoi has been interpreted as a misspelling of the word Suiones, which denoted Svear, i.e. Swedes. After analysing the texts of ancient authors, Thomas Grane expressed his view that their authors' knowledge of northern territories was extremely vague (Grane 2007: 17-18). Other authors (e.g. Grünthal 1997: 245, 247) too consider the references found in ancient writings rightfully dubious. Information is too scarce and sometimes even contradictory; thus it is not possible to prove or reject a hypothesis on possible references to Livonian people, since the people mentioned could not be located properly or their residence description is outright unrealistic. However, it is entirely possible that this ethnonym may have been attributed to Livonians only later and was first used to denote another people, similarly to the word aestii used by Tacitus (see EES 58).

Several centuries later Alfred the Great, the 9th century King of Wessex, and Adam of Bremen in the 11th century mention a people living east of the river Don whom the Saxons call Liubene (also Liobene). The location given indicates anything but Livonians; the phonetic composition, meanwhile, coincides with the ethnonym любь used in Old Russian chronicles (Grünthal 1997: 247).

\section{Scandinavian sources}

If we look at the occurrence of historical events, the earliest mention of Livonians with their appropriate ethnonym may be - but is not necessarily - found in the eighth book of Gesta Danorum ("the heroic history of the Danes") written by Saxo Grammaticus and completed in ca 1185 (being first published in 1514). In it he describes the battle of Bråvalla, which may have taken place in the year 550 or 750 , in which 
Liui Saxonumque ("Livonians with Saxons") participated and where Liuorum regis filius Bicco ("Bicco, the son of the Livonian elder") was taken prisoner (SGD 261, 279, 280). Elsewhere the text mentions someone Ger Liuicus called "Ger the Livonian", or possibly "Ger from Livonia" (SGD 258; see also Saxo 2006: 239, 256, 257). This reference is doubtful; according to some researchers the battle never took place, while others believe that what is described there was a battle that took place some time around the year 1000 - since this chronicle is a mixture of historical and mythological sources (Koski 2011: 57-58; Zemitis 2011: 75). If we date it by the time the chronicle was recorded, this mention of the Livonians is among the earliest, but is not the first.

If the names mentioned were really the personal names of Livonians, the Latinised name Bicco (Scandinavian Bikki) ${ }^{1}$ could be phonetically linked to the appellative *pikkoi 'small, little', cf. Votic pikkarain, Fennic pikku, Pikko (the name of a small lamb), Piko (the name of a person), Aunus pikkaraine, pikoi pikkoi 'a little', etc. In this case, the word is an -oi diminutive, which in the latter period of the Livonian language existed only in rudimentary form (Mägiste 1928: $1-3,74,100-101)$. The problem here is posed by the fact that the stem, *pikk-oi 'short', has not been recorded in Livonian (or Estonian), but they do have a word piški- with this meaning, e.g. 15821583 Matte Piszkelemmitte and others (Kiparsky 1938: 254; Stoebke 1964: 63). At the same time, it is not entirely impossible that at some point in the past this stem formed part of Livonian vocabulary. Even less probable is connecting the name Bicco with the Livonian appellative pitkā 'tall, long', e.g. Livonian 1290 Pittekeleybe (Feuerabend 1985: 241) < *pitkä-leipä (cf. pitkā + lēba 'bread'). However, we do not find similar anthroponyms among old Scandinavian male names (ONMN).

The name Ger is too short to base any uncontroversal conclusions upon it. Among the possibilities are the Finnic stems *Ker- and *Kēr-, such as Estonian Hans Kerropoyck from 1534, Finnish Kero(i) from the 16th century, Kierikainen (Geri-) from 1374 and Kiero from the 16th century (Stoebke 1964: 37, 165). These could be linked to some appellatives, such as kerä 'ball, globe', kiero 'crooked, distorted; deceptive; askance', kierre 'coil', etc. On the other hand, we cannot rule out Germanic names, cf. compound stems such as Gerhard (cf. old High German gēr 'spear', hard 'hard, brave'), Germar (cf. māri 'famous'), Gerolf (gēr and wolf), etc. (Nauman et al. 1984: 41, 42). It

1 Bikki as the name of a disloyal adviser of a king is known from Skáldskaparmál, a part of the Prose Edda (early 13th century) and the Volsunga Saga (late 14th century). 
is not possible to immediately associate this name from the text by Saxo Grammaticus with the old Scandinavian word geirr 'spear' (see ONMN).

Reliable written records of Livonians are only found after the year 1000 , but these take the form of mentioning the lands of the Livonians, i.e. Livonia. From the beginning or first half of the 11th century is a text on the Åda runestones of Södermanland (Söd. 39): h[an] trukn-pi . // . a lf. lanti [a Liflandi] 'he was drowned in Livonia', and another in Vekholm church in Uppland (UP. 698): han . ut fai . a liflainpi 'he fell in faraway Lifland' (Mel'nikova 2001: 308, 324; Koski 2011: 57). Both texts contain the parts lif- 'Livonian' and -land. Therefore we have here a typical Germanic name, similar to the German land name Livland used later (Koski 2011: 54). The Scandinavian texts also include locations containing the names of people, such as Kúrland, Virland 'Virumaa' (a region on the north Estonian coast), Refaland 'Rävalamaa' (cf. refalir 'people of Refaland'; Reval - the German name of Tallinn) and Kirjálaland 'Karelia' (cf. kirjálir 'Karelians'; Dzhakson 2001: 30, 33-35). Therefore the first time the Livonians are mentioned in written sources indirectly is during the first half of the 11th century. In rune inscriptions there are also place names from Livonia or nearby, such as $i$. tuna . asu (Söd. 121) 'at the mouth of the river Daugava' (if we read $i$ Dyna ósa), um . tumisnis (Söd. 198) 'round Kolka Cape' (cf. Germ. Domesnes), a . uit,au [most probably Vindan] (Gotl. 135) 'River Venta', etc. (Mel'nikova 2001: 299, 302, 307). Thus, the rune stones bear witness to the visits Scandinavians made to the lands of the Kuronians and Livonians in the early 11th century; they have collected tribute from Kuronians as long ago as in the 9th century (Saxo 2006: 31).

\section{Old Russian sources}

The first or second event on the timescale describing the ethnos of Livonians is found in an Old Russian chronicle entitled "Повесть временных лет" (Tale of Bygone Years), but this source too is uncertain. The chronicle tells us about a peace treaty between the Rus and the Greek in 944 or 945, where according to E. A. Melnikova the name of one member of the delegation could refer to a Livonian. In various copies of this document the spelling of the name varies: Либиар Фастов, Либи арьфастовъ, Либиарфостов, Либи Аръфастовъ оr Либи Арьфастов (PVL 97, PSRL 35, Mel'nikova 2001: 327-328). The researcher has linked this name to the Scandinavian anthroponym Arnfastr ( $\mathrm{grn}$ 'eagle', fastr 'fast'), which has also been 
found in a Swedish rune stone inscription dated between 1020 and 1060. It is rather a common male name in Old Swedish and Old Danish, but also in the Norse language, and in rune texts, including the form arfast $\sim$ arfastr, where the meaning of fastr is not 'fast', but 'firm, strong' (ONMN). If the comparison drawn by E. A. Melnikova is correct, this really is one of the earliest Livonian names. It is a Scandinavian name. The early presence of Scandinavians in the area of the Livonian settlements in Kurland is also reflected in archaeological finds from the 7th and 10th centuries (Zemittis 2011: 78), and the early dealings between Scandinavians and Russians is a wellknown fact.

If this guess by E. M. Melnikova holds, Libi may be an ethnonym derived from Latvian or Livonian, cf. Latvian lībis 'Livonian', Livonian līb lībe (1767 Liebi) 'Livonian' (Winkler, Pajusalu 2009: 108109). It is unsure whether this ethnonym was originally pronounced with a $b$ or not. A. Zaliznyak has analysed early Finnic and Scandinavian loans and proposes that using the letter $\sigma$ to express the sound $/ \mathrm{v} /$ from the source language indicates loaning the word through the dialect spoken in the Pskov-Novgorod region (Zaliznyak 2004: 55). The singular form of the ethnonym would then be либинь (see also below).

This contract with the Byzantine Empire was most probably written in Greek or Old Russian, since there are also records about the use of the latter dating to before the conversion of Russia to Christianity in the late 10th century (Možejko, Ignatenko 1988: 32-34). S. M. Mikheyev (2011: 198) states that the texts of the contracts made with the Rus, together with stories about how the contract was made, originate from the chronicle of Georgios Amartolos, who lived in the 9th century, or rather from the amendments to this chronicle made before 948, whose authorship is attributed to Symeon the Logothete (Russian Логофеm) who lived during the next century (Xronika; Mixeev 2011: 198). But this chronicle and its various versions and translations would be an entire research topic in itself.

With no specific date presented, this chronicle lists Livonians among the peoples paying tributes to Russia: "Въ Афетови же части сбдить русь, чюдь и вси языць: меря, мурома, всь, мордва, заволочьская чюдь, пермь, печера, ямь, югра, литва, зимигола, корсь, льтгола, либь." (PVL 62, 64) 'In the lands of Japheth there live Russians, Chudes and other peoples, such as Merya, Muroma, Ves, Mordvin, Zavolochska Chudes, Perm, Petchera, Yam, Ugra, Lithuanians, Semigallians, Curonians, Letigalls and Livonians'. The last word is the collective noun syncretistically denoting both the people and the land. Similar to many other ethnonyms it contains the 
letter $\mathrm{b}$, which in this period was pronounced as an extremely short, reduced $i$ [1] (Možejko, Ignatenko 1988: 104). According to M. Vasmer, this Old Russian word is a loan word from Latvian, cf. lībis 'Livonian' (Fasmer I 305; see also Grünthal 1997: 247). If we look at the time of writing, it is the second mention; but if we consider the content of the document, it is the earliest mention of the Livonians. In communicating the dating of this entry of the chronicle, written records are vague, so the dating is given according to the time the chronicle was written.

According to Latvian archaeologist Guntis Zemītis (2011: 75), the first mention of Livonians in historical documents dates from 1113 the dating derived from the time the chronicle containing it was written. The same year has also been given as the first mention of the Livonians by Eduard Vääri (2005: 111). To say that PVL was written in the 12th century (Boiko 1998: 5) is too approximate, but to say that it was written during the late 11 th or early 12 th century is also inexact (Koski 2011: 54). This precision (1113) derives from Old Russian literary history (e.g. Prokofyev 1988: 6; Kuskov 1998: 50, 54). Academician A. A. Shakhmatov supposed it in several of his works more than a hundred years ago.

In other sources of Old Russian literary history the dating of this chronicle is given as "around 1113" (see e.g. Dmitriev 1990: 8; Dëmin 2008: 24). Such dating is more accurate. The first version of PVL has not been preserved, but it was included in later chronicles, which were rewritten multiple times, and this is why it is not clear what the last year was that was recorded by the monk Nestor from the Kyiv Pechersk Lavra monastery. Educated guesses have been 1110, 1113 and 1115 (Tvorogov 1996: 139). We must agree with the Old Russian philologist Sava Mikheyev that the chronicle could not have been written before 1113 when Duke Sviatopolk Iziaslavich died, but also not later than 1116 when hegumen Sylvester from the Vydubychi Monastery near Kyiv composed the new (second), radically reworked version of this chronicle on the orders of Grand Duke Monomakh (1053-1125) (Mixeev 2011: 31). From this we grasp that, according to our current knowledge, Livonians were first mentioned in the early 12th century - more precisely during the second decade of the century. The oldest preserved manuscripts of the Tale of Bygone Years are only from the 14th and 15th centuries (Kuskov 1998: 50).

In writing his chronicle, Nestor used the second Kyiv Pechersk chronicle ("Начальный свод"), which was based on the earliest chronicle composed in Kyiv (“Древнейший Киевский свод”); the latter was composed using the texts of the first Kyiv Pechersk chronicle ("Первый Киево-Печерский свод", 1073) and the old 
chronicle of Novgorod (“Древний Новгородский свод”, 1050) (Kuskov 1998: 50). The information concerning Livonians was most probably taken from this last source. Thus the first mention of the Livonians could be from the late 11th century, but clear evidence proving it has not been preserved. Indirectly, the link that refers to the lands of Novgorod is the spelling of the word либь (see above).

Next we shall discuss the text written on a $41 \times 9 \mathrm{~cm}$ strip of birch bark found in Novgorod that was written for a Livonian merchant who lived in Pskov. This text begins as follows: "Грамота оть Їли ї оть Дъмитра Пльсковљ ко либинљ ко Мостокь", which in modern Russian would be "Грамота от Ильи и от Дмитра во Псков кливу Мостке", i.e. "Letter from Ilya and Dmitri to the Livonian M. in Pskov'. This letter is proof that Livonians were active in the field of commerce in Novgorod and other towns during the Middle Ages (Zaliznyak 2004: 308).

This historical item (No 776) was discovered in Novgorod, 2.3-2.4 metres underground. Its stratigraphical dating was between 1130 and 1150; non-stratigraphical methods gave the dating as between 1140 and 1170 . The most probable time of writing of the letter is considered to be some time between 1140 and 1150 (Yanin et al. 2004: 10). By the time of its writing, it is the third mention of Livonians.

This letter contains the ethnonym либиноу. The singular nominative of this word is либинъ [libinü] (Zaliznyak 2007: 308). The stem of the ethnonym is либ-, while -инъ is the suffix of singularity in Old Russian (Demyanov 2001: 350). The same suffix has also been used to denote members of other Finno-Ugric peoples (see Saarikivi 207: $208 \mathrm{ff})$.

This record is another example of this ethnonym being spelled with the consonant $b$ in Old Russian. This tradition continued in the following centuries, albeit in the form of the plural denomination либь $\sim$ любь. As such, we can see that the records of this ethnonym present two lineages: (1) the Germanic (Vikings and Germans) with the letter $f$; and (2) the Latvian and Russian, with the letter $b$.

Another intriguing aspect of this item is the dative form of the personal name ко Мостокь, of which the nominative would be *Mostoka. A. A. Zaliznyak gives its presumed original form as Мъстъка [Mŭstŭka] and links it to the Finnic appellative musta 'black', which has the appended diminutive suffix $-\imath k-a$. In his opinion, the latter is more typical of Russian than Finnic languages. A. A. Zaliznyak presents the toponyms Мстино $\sim$ Мустино селище and Мостин ручей as indirect evidence of the occurrence of Musta as an anthroponym in the lands of Novgorod (Zaliznjak 2004: 308-309). Janne Saarikivi thinks the original form of the anthroponym was either 
Mostok or Mostoka, and states that this needs some research before we can declare it has either a Slavonic or Finnic suffix (Saarikivi 2007: 235). The form Mostok has been definitely ruled out, because the dative $-b$ is added to substantives ending in Nominative with the letter $a$ only.

Taking into consideration the Finnic names, we can reconstruct it as either *Musta-kka, *Must-u-kka or *Must-oi-kka. Such name is not recorded earlier (a point on which A. A. Zaliznjak agrees) or later. Undoubtedly, this name could be linked to the appellative *musta (cf. Livonian musta, Estonian must), because personal and animal names with the stem must- but without any suffix have been recorded among Livonians, Estonians and others, e.g. the Livonian names 1453 Jacop Must, 1506 Magdalene Must, 1582-1583 Michell Most, Estonian 1350 Mustehermen (<*Musta Hermann), 1468 Most, Hans, and Finnish compound words such as Mustapää, Mustasilmä from the 15th century (Kiparsky 1938: 253; Feyerabend 1985: 24; Stoebke 1964: 168).

The anthroponym *Mustakka has the appended diminutive suffix $-k k a$, which is most probably of Finnic origin. This suffix is quite common in old Finnic names and common nouns, cf. *Ilmakka, *Meelikka, *Toivakka; Finnish punakka 'reddish' from puna 'redness' (Stoebke 1964: 121; Laanest 1975: 136).

In addition to $*_{-k} k a$, the name can include another diminutive suffix: either *- $u$ or $*$-oi. After Julius Mägiste, the suffix $-u \sim-o$ in the Estonian Mustu $\sim$ Musto (a cow's or ox's name), mustu 'seal with dark skin', and -o in Finnish Musto (a cow's name) derive from *-oi but in fact their differentiation in Livonian and Estonian is impossible (cf. Mägiste 1928: 12, 71, 214).

The correspondence between the Finnic $u$ and the Russian $o$ could be found also in birch bark writings ( въ Hou 'in Nuija' < nuija 'club') and from old loan-words in Russian, such as the Finnic kuva 'picture, boot last' and the Russian кова кува 'shadow' (Kalima 1919: 50; Xelimskij 2000: 348). In successive syllables there is potential correspondence between the Finnic $a$ and $o$ and the Russian $o$, for example the Karelian koppala and the Russian копало $\sim$ копала 'wood shegrouse' (Kalima 1919: 65; Myznikov 2003: 133), which could also have been reflected in some versions of the name Ar'fastov $\sim$ Arfostov mentioned above (ПСРЛ ІІ 35). 


\section{Later records}

According to Marek Tamm (2009: 8), the first mention of Livonia in Latin prose texts in form in Liflandiam is in a message sent in $1195 / 1196$ by Sido, the provost of the Augustinian monastery in Neumünster, to Gozwinus, a priest in Haseldorf. This time it is again the name of a land derived from the name of the people, and the source language here is German. From the 13th century, the most important source on Livonia and Livonian personal names is the Livonian Chronicle of Henry, but the discussion of these names in this text deserves separate research (see Vääri 2005).

\section{Conclusions}

Sorting the above information by the times of the events (number before slash) or by the times of its recording (number after slash), we can summarise written sources on Livonians in the form of the following table 1. The asterisk before the number indicates an uncertain event. If we consider the dating of the event, the earliest sources mentioning Livonians are Gesta Danorum and the Tale of Bygone Years, but both sources present rather dubious information: in the first the battle of Bråvalla itself or the year are dubious; in the latter we cannot be sure that the member of the delegation was really a Livonian. If we consider the time of recording, the earliest sources are two rune inscriptions from Sweden, and the next is the list of neighbouring peoples of the Russians from the Tale of Bygone Years.

Table 1. Earliest written sources on Livonians

\begin{tabular}{l|l|l|l|l} 
No & $\begin{array}{l}\text { Writings, grave } \\
\text { inscriptions and } \\
\text { historic documents }\end{array}$ & $\begin{array}{l}\text { Time of } \\
\text { event(s) }\end{array}$ & $\begin{array}{l}\text { Dating of } \\
\text { writing }\end{array}$ & $\begin{array}{l}\text { Oldest } \\
\text { preserved } \\
\text { version of text }\end{array}$ \\
\hline $1 * / 4^{*}$ & Gesta Danorum & $\begin{array}{l}550,750, \\
\sim 1000 \text { or } \\
\text { never took } \\
\text { place }\end{array}$ & $\begin{array}{l}\sim 1186 \text { or } \\
1208\end{array}$ & $\sim 1275$ \\
\hline $2 * / 2$ & $\begin{array}{l}\text { Tale of Bygone } \\
\text { Years (2 references) }\end{array}$ & $\begin{array}{l}\text { 944 or } 945 ; \\
\text { second one } \\
\text { undated }\end{array}$ & $1113-1116$ & 1377 or later \\
& und &
\end{tabular}


Table 1. Continuation

\begin{tabular}{l|l|l|l|l} 
No & $\begin{array}{l}\text { Writings, grave } \\
\text { inscriptions and } \\
\text { historic documents }\end{array}$ & $\begin{array}{l}\text { Time of } \\
\text { event(s) }\end{array}$ & $\begin{array}{l}\text { Dating of } \\
\text { writing }\end{array}$ & $\begin{array}{l}\text { Oldest } \\
\text { preserved } \\
\text { version of text }\end{array}$ \\
\hline $3 / 1$ & $\begin{array}{l}\text { Two stones with } \\
\text { rune inscription }\end{array}$ & $\begin{array}{l}\text { Early } 11 \text { th } \\
\text { century }\end{array}$ & $\begin{array}{l}\text { Early 11th } \\
\text { century }\end{array}$ & $\begin{array}{l}\text { Early 11th } \\
\text { century }\end{array}$ \\
\hline $4 / 3$ & Letter on birch bark & $\begin{array}{l}1140 \text { s or } \\
1150 \text { s }\end{array}$ & $\begin{array}{l}1140 \text { s or } \\
1150 \text { s }\end{array}$ & 1140 s or 1150 s \\
\hline $5 / 6$ & $\begin{array}{l}\text { Livonian Chronicle } \\
\text { of Henry }\end{array}$ & $\sim 1184-1227$ & $1224-1227$ & 14 th century \\
\hline $6 / 5$ & $\begin{array}{l}\text { Message sent by } \\
\text { Sido }\end{array}$ & 1195 or 1196 & 1195 or & 1195 or 1196 \\
& & 1196 &
\end{tabular}

\section{Acknowledgements}

I would like to thank Prof. Karl Pajusalu and Prof. Riho Grünthal for helpful comments. Special thanks to Mariko Faster for a necessary literary reference material.

\section{Address}

Enn Ernits

Institute of Veterinary Medicine and Animal Sciences

Estonian University of Life Sciences

Kreutzwaldi 62

51014 Tartu

E-mail: enn.ernits@emu.ee

\section{References}

Boiko, Kersti (1998) "Liivlased ja liivi keel". [The Livs and the Livonian.] In Jaan Õispuu, ed. Kaheksa keelt, kaheksa rahvast, 5-13. [Eight languages, eight peoples.] Tallinn: TPÜ Kirjastus.

Dëmin, A. S. (2008) "Povest' vremennyx let". In Istorija drevnerusskoj literatury: analitičeskoe posobie, 24-44. Moskva: Jazyki slavjanskix kul'tur.

Dem'janov, V. T. (2001) Inojazyčnaja leksika $v$ istorii russkogo jazyka: problemy morfologičeskoj adaptacii. Moskva: Nauka.

Dmitriev, L. A., ed. (1990) Literatura drevnej Rusi: xrestomatija. Moskva: Vysšaja škola. 
Džakson; T. N. (2001) Austr i görðum: drevnerusskie toponimy v drevneskandinavskix istočnikax. (Studia historica. Series minor.) Moskva: Jazyki slavjanskoj kul'tury.

EES (2012) = Metsmägi, Iris, Meeli Sedrik, Sven-Erik Soosaar, eds. Eesti etümoloogia sõnaraamat. [Etymological dictionary of the Estonian language.] Tallinn: Eesti Keele Sihtasutus.

Fasmer, Maks [= Vasmer, Max] (1986) Ètimologičeskij slovar' russkogo jazyka 2. Izdanie 2-e, stereotipnoe. Moskva: Progress.

Feyerabend, Liselotte (1985) Die Rigaer und Revaler Familiennamen im 14. und 15. Jahrhundert: unter besonderer Berücksichtigung der Herkunft der Bürger. (Quellen zur baltischen Geschichte, 7.) Köln; Wien: Böhlau.

Grane, Thomas (2007) "Did the Romans Really Know (or Care) about Southern Scandinavia? An Archaeological Perspective". In Thomas Grane, ed. Beyond the Roman frontier. Roman influences on the Northern Barbaricum, 7-30. (Analecta Romana Instituti Danici. Supplementum, 39.) Roma: Edizioni Quasar, 2007. Available at $<\mathrm{http} / / /$ varpelev.saxo.ku.dk/publikationer/Roman_sources_to_Scandinavia_2007.pdf/>. Accessed on 24.01.2014.

Grünthal, Riho (1997) Livvistä liiviin. Itämerensuomalaiset etnonyymit. [From Livvian to Livonian: the Finnic ethnonymes.] (Castrenianumin toimitteita, 51.) Helsinki: Suomalais-ugrilainen laitos, Suomalais-Ugrilainen Seura.

Xelimskij, E. A. (2000) Komparativistika, uralistika: lekcii i stat'i. Moskva: Jazyki russkoj kul'tury.

Xronika $=$ Xronika Georgija Amartola . Available at $<$ http://lib.pushkinskijdom.ru/Default.aspx?tabid=4705> . Accessed on 22.01.2014.

Janin et al. (2004) = Janin, V. L., A. A. Zaliznjak, A. A. Gippius (2004) Novgorodskie gramoty na bereste 11: (Iz raskopok 1997-2000 gg.). Moskva: Russkie slovari.

Kalima, Jalo (1919) Die ostseefinnischen Lehnwörter im Russischen. (Suomalaisugrilaisen Seuran toimituksia, 44.) Helsinki: Suomalais-ugrilainen Seura.

Kiparsky, V. (1938) "Ostseefinnische Personennamen aus lettländischen Sammlungen”. In Opptatud Eesti Seltsi aastaraamat 1936, 245-259. [Yearbook of the Learned Estonian Society 1936.] Tartu: Õpetatud Eesti Selts.

Koski, Mauno (2011) “Mis on Liivimaa erinevatel aegadel olnud?" [What has Livonia been in different times.] In Renāte Blumberga, Tapio Mäkeläinen, and Karl Pajusalu, eds. Liivlased: ajalugu, keel ja kultuur, 53-73. [The Livs: History, Language and Culture.] Tallinn: Eesti Keele Sihtasutus.

Kuskov, N. N. (1998) Istorija drevnerusskoj literatury. Izdanie 6e, ispravlennoe i dopolnennoe. Moskva: Vysšaja škola.

Laanest, Arvo (1975) Sissejuhatus läänemeresoome keeltesse. [Introduction to the Finnic languages]. Tallinn: Eesti NSV Teaduste Akadeemia Keele ja Kirjanduse Instituut. 


\section{Enn Ernits}

Mägiste, Julius, (1928) oi-, eid-deminutiivid läänemeresoome keelis: läänemeresoome nominaaltuletus I. [oi- and ei-deminutives in the Finnic: nominal derivation in the Finnic languages.] (Acta et Commentationes Universitatis Tartuensis (Dorpatensis) B XII 2 .) Tartu.

Mel'nikova, E. A. (2001) Skandinavskie runičeskie nadpisi: novye naxodki i interpretacii. Teksty, perevod, kommentarij. (Drevnejšie istočniki po istorii Vostočnoj Evropy.) Moskva: Vostočnaja literatura.

Mixeev, S. M. (2011) Kto pisal "Povest' vremennyx let”? (Slavjano-germanskie issledovanija, 6.) Moskva: Indrik.

Myznikov, S. A. (2003) Russkie govory Obonež'ja: areal'no-ètimologičeskoe issledovanie leksiki pribaltijsko-finskogo proisxoždenija. Sankt-Peterburg: Nauka.

Možejko, N.S., A. P. Ignatenko (1988) Drevnerusskij jazyk. 3-e dopolnennoe izdanie. Minsk: Vyšèjšaja škola.

Naumann jet al. (1984) = Naumann, Horst, Gerhard Schlimpert, Johannes Schultheis 1984. Das kleine Vornamenbuch. Leipzig: VEB Bibliographisches Institut.

ONMN = Old Norse men's names. Available at $<$ http://www.vikinganswerlady.com/ONMensNames. shtml $>$. Accessed on 23.01.2014.

Prokof'ev, N. I., ed. (1988) Drevnerusskaja literatura: xrestomatija. Izdanie 2e, dopolnennoe. Moskva: Prosveščenie.

PSRL (1998) = Polnoe sobranie russkix letopisej 2: Ipat'evskaja letopis'. Moskva: Jazyki russkoj kul'tury.

PVL (2007) = "Povest' vremennyx let". In Biblioteka literatury drevnej Rusi 2. SanktPeterburg: Nauka, 62-315.

Saarikivi, Janne (2007) "Finnic Personal Names on Novgorod Birch Bark Documents". In Juhani Nuorluoto, ed. Topics on the ethnic, linguistic and cultural making of the Russian North, 196-246. (Slavica Helsingiensia, 32.) Helsinki: Helsinki University.

Saxo (2006) = Saxo Grammaticus. The History of the Danes. Hilda Ellis Davidson, ed., translated by Peter Fisher. Foodbridge, Rochester: D. S. Brewer.

SGD (1886) = Saxonis Grammatici Gesta Danorum. Alfred Holder, ed. Strassburg: K. J. Trübner, 1886. Available at $<$ http://archive.org/details/saxonisgrammati00holdgoog $>$. Accessed on 23.01.2014.

Stoebke, Detlef-Eckhard (1964) Die alten ostseefinnischen Personennamen im Rahmen eines urfinnischen Namensystems. Hamburg: Leibniz-Verlag.

Tamm, Marek (2009) Liivimaa leiutamine: Ida-Baltikumi religioosne ja geograafiline kujutamine 13. sajandi esimesel poolel. [Inventing Livonia: Religious and Geographical Representations of the Eastern Baltic Region in Early 13th Century.] (Tallinna Ülikool: humanitaarteaduste dissertatsioonid.) Tallinn: Tallinna Ülikool. Available at $<$ http://e-ait.tlulib.ee/29/1/tamm_marek1.pdf $>$. Accessed on 25.01.2014. 
Tvorogov, O. V. (1996) "Povest' vremennyx let". In O. V. Tvorogova, ed. Literatura drevnej Rusi: biobibliografičeskij slovar', 139-141. Moskva: Prosveščenie: Učebnaja literatura.

Vääri, Eduard (2005) "Liivi kiri ja kirjakeel". [Livonian writing system and written language.] In Eerik Teder, ed. Raamat on... 4: Eesti bibliograafia ja raamatuloo almanahh, 111-126. [Almanack of Estonian Bibliography and Book History, 4.] Tallinn.

Winkler, Eberhard, Karl Pajusalu (2009) Salis-livisches Wörterbuch. (Linguistica Uralica. Supplementary Series, 3.) Tallinn: Teaduste Akadeemia Kirjastus.

Zalizjak, A. A. (2004) Drevnenovgorodskij dialekt. 2e izdanie, pererabotannoe s učetom materiala naxodok 1995-2003 gg. Moskva: Jazyki slavjanskoj kul'tury.

Zemītis, Guntis (2011) "Liivlased: vanim ajalugu (10.-16. sajand)". [Oldest history of the Livs (from 10th to 16th century).] In Renāte Blumberga, Tapio Mäkeläinen and Karl Pajusalu, eds. Liivlased. Ajalugu, keel ja kultuur, 75-104. [Livs: history, language and culture.] Tallinn: Eesti Keele Sihtasutus.

Kokkuvõte. Enn Ernits: Liivlaste nimetustest ja nimedest vanimates kirjamälestistes. Käesolevas artiklis üritatakse panna paika liivlasi tähistavate etnonüümide ajaline järjestus, täpsustatakse nende kronoloogiat, analüüsitakse rahvanimetusi ja võimalikke liivi isikunimesid. Sündmuste toimumise aja järgi otsustades on kõige varasemateks kroonikateks, milles räägitakse liivlastest, "Taanlaste teod" ja "Jutustus möödunud aegadest", ent mõlemad on üsna kahtlased teated: esimesel juhul on kahtluse all Bråvalla lahingu pidamine üldse või selle toimumise aeg (VI, VIII või XI saj), teises allikas pole aga kindel, kas Kiievi ja Bütsantsi vahelise rahulepingu sõlmimise (944 või 945) juures viibis üks liivlane. Teose loomise aega arvestades on kõige varasemateks liivlasi (täpsemini küll Liivimaad) nimetavateks allikateks kaks ruunikiviteksti Rootsis, mis pärinevad kas XI saj algusest või hiljemalt esimesest poolest. Sellele järgneb tõenäoliselt aastate 1113-1116 vahemikus kirjutatud "Jutustuses möödunud aegadest" leiduv dateerimata loetelu venelaste naaberrahvastest. Iseenesest üsna problemaatilistest liivi isikunimedest tulevad kirjutises kõne alla "Taanlaste tegudes" esinevad Bicco ja Ger ning "Jutustuses möödunud aegadest" mainitav Либи Аръфастовъ. Esimene kindel liivi isikunimi on *Musta-kka, *Must-u-kka või *Must-oi-kka (<*musta 'must') ühes Novgorodist avastatud kasetohtürikus, mis on kirjutatud tõenäoliselt 1040.-1050. aastate paiku.

Märksõnad: liivlased, läänemeresoome rahvad, etnonüümid, antroponüümid, onomastika 
Kubbõvõttõks. Enn Ernits: Līvlizt nimtõkst ja nimūd amā vaṇīmižis kērandõks ovātis. Sīes kēras sōb kōḷdõd pānda paikõl līvlizt rovnimtõkst āigali kỗrda, pienõstõ nimtõkst kronolōgijõ, pēţõb rovnimtõkši ja võibiži līvõ pärsōnnimīdi. Suggimizt tuoimimiz āiga pierrõ loptāntõs amā varālizt attõ kronikad, kus rõkāndõb il̦ līvlizt, "Dēņlizt tīemizt" ja "Nīžõm iḷ piddõz lǟnõd àigad", bet mỏlmis attõ kōdštõb tīetõd: ežmis um amāleb kōdštõb Bråvalla taplimi, nei ǐž ka āiga, kunā se vỏ (̦ (6., 8. agā 11. āigastsadā), tuois ovātõs äb ūo sieldõ, või Kīev ja Bizantij vailiz armsādimiz klõkšimiz jūsõ (944 agā 945) vỏl ka ikš līvli. Až vaņţlõb lūomiz aigõ, siz amā varālizt ovātõd, kus līvlizt (agā Līvõmō) sōbõd nimtõd, ātõ kakš rūnkivtekstõ Rūotšmōl. Ne àtõ perīn XI āigastsadā īrgandõksõst agā amā obbõm ežmist pūolstõ. Pierrõ siedā tulāb ilzõluggimi krīevõd kāimarovšti, mis um lieudtõb arrõb ku 1113-1116 kēratõd kronikas "Nīžõm iḷ piddõz länd āigad". Ǐžeņtšõst problemātližist līvõ pärsōnnimīst sōbõd vaņţõltõd Bicco ja Ger "Dēņlizt tīemizist" ja Либu Аръфастовъ, mis um ovātõs "Nīžõm iḷ piddõz länd āigad". Ežmi sieldõ līvõ pärsōnnim um *Musta-kka, *Must-u-kka agā *Must-oi-kka (< *musta 'mustā') īds Novgorodstõ lieudtõd tūoigõkēras, mis um kēratõd arrõb ku 1040.-1050. ā. immõr. 